\title{
Investigation of the Relationship Between the Dominant Brain Areas, Risk-Taking and Alexithymia of Outdoor Adventure Recreation Participants
}

\author{
Sirri Cem Dinc ${ }^{1} \&$ Ozge Yavas $\mathrm{Tez}^{2}$ \\ ${ }^{1}$ School of Sport Sciences and Technology, Nevsehir Haci Bektas Veli University, Nevsehir, Turkey \\ ${ }^{2}$ Medical Sciences Institute Department of Sport Sciences (PhD), Ankara University, Turkey \\ Correspondance: Sirri Cem Dinc, Nevsehir Haci Bektas Veli University, School of Sport Sciences and \\ Technology, 2000 Evler Mah. Damat Ibrahim Pasaa Kampusu H Blok, Nevsehir, Turkey. E-mail: \\ scem.dinc@gmail.com
}

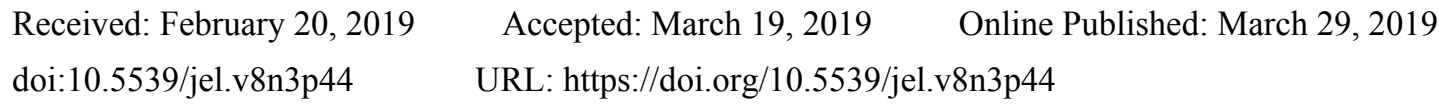

\begin{abstract}
The aim of this study is to investigate the relationship between dominant brain areas, alexithymia and risk-taking behavior levels of nature and adventure recreation participants. The study was carried out on 652 outdoor adventure recreation participants in different categories (air, land, water) between the years 2016-2017. After meeting normality and homogeneity of data obtained from participants of nature and adventure recreation, it was based on the mediator influence analysis method, which was established by Baron and Kenny (1986, 1176), in order to determine whether alexithymia and extrovert thinking play a mediator role in the relationship between brain dominance and risk-taking behavior. In addition, the significance of stepwise regression analysis results was checked by Sobel Test. The results show that nature and adventure recreation participants with a high level of alexithymia and with extrovert personality tend to take more risks.
\end{abstract}

Keywords: outdoor adventure recreation, the dominant brain areas, alexithymia, risk-taking

\section{Introduction}

\subsection{Brain and Brain Dominance}

The brain, which is the most complex structure in the universe and called the mysterious region, has attracted people's attention since the early ages and has been a subject of research in many areas. This situation brings with the question "Can we use enough of our brain that has great potential?" and it has often been questioned. The brain, known as the Sleeping Giant and called the Cerebrum in medicine, consists of about 100 billion neurons, and right and left hemispheres covered by the brain membrane. Research on the brain, of which is $78 \%$ water, $10 \%$ fat and $8 \%$ protein of its structure, show that however it is about 1300-1400 grams of weight in an adult human, its surface area is $2000-2100 \mathrm{~cm}^{2}$ and only $1-2 \%$ of its capacity can be used (Jensen, 1998). Unfortunately, not many things are known about the human brain, in which many studies have been conducted and many articles have been written.

The brain is generally divided into five regions: occipital, frontal, parietal, temporal cortex and cerebellum. In addition to these lobes which have different functions and tasks, hippocampus, thalamus, hypothalamus, and amygdala are responsible for the production of many of the brain chemicals, which form other structures of the brain and are called the limbic system, located in the central part of the brain. Hippocampus has important functions related to the formation of new memories, learning, memory, direction, and emotions. Thalamus, which provides the nerve transmission to the brain hemispheres and the region where all sensory stimulation occurs, provides the secretion of natural hormones such as adrenalin in danger, fear, excitement, and emergencies together with the control of our primitive behaviors (laughing, crying, etc.). Hypothalamus is located right beneath the thalamus in the brain and is responsible for the body's basic needs such as hunger, toughness, thirst, sleep, sexuality, and controlling body temperature, water balance, and metabolism. Amygdala, located just below the hypothalamus and an important region for our body, stores our memories related to our emotional and social life. In addition, it is responsible for our reactions to emotions and helps us empathize by feeling our emotions in fear, excitement, joyful moments. Sensory Cortex takes charge in the execution of high 
function tasks such as sensory perceptions, physical sensations, visual stimuli, behavior planning, awareness-level (Wolfe, 2001; Stevens \& Goldberg, 2001; Jensen, 1998).

James Olds experimented with rats with the help of Skinner Mechanism discovered by Skinner at the beginning of the 1930s. According to the results, it has been proven that the ventral tegmental and nucleus accumbens areas, called limbic regions in the brain, are the center of joy and pleasure of the brain and dopamine is responsible for the transmission between the neurons (Olds \& Milner, 1954; Uzbay, 2015). However, it is known that the natural reward areas that occur involuntarily through our stimulations such as eating, love, reproduction are the factors in the release of dopamine, it can cause dopamine release in behaviors such as "taking risks, gambling and sex" especially in many stimulant substances such as alcohol, cocaine and, nicotine, which are seen as unnatural reward pathways (Karabekiroğlu, 2008). Dopamine secreted during the activity or work performed by the individual willingly varies depending on the state of the individual. In other words, if an activity or work triggers a high level of dopamine released in an individual's brain, it can be said that the individual is experiencing a sense of pleasure due to his or her condition. Cells also perform more depending on the release of dopamine. Otherwise, reluctance and negative feelings are observed with the decrease of dopamine levels in the individual (Üngüren, 2015).

In fact, the brain, considered as a single structure by many people, consists of two hemispheres of the brain connected by bundles of nerve fibers inside the skull but only one consciousness. These two hemispheres of the brain are connected to each other by nerve fibers called corpus callosum. It is known that this nerve fiber provides information exchange by serving as a bridge between two brain hemispheres (Pençe, 2000). These fibers provide functional integrity through cross-linking, creating a symmetrical structure in the human body (Wagenen \& Herren, 1940). In other words, the brain hemispheres provide control of the body through cross-links.

\subsection{Brain Dominance and Alexithymia}

Hermann, who specializes in brain research spanning nearly twenty years to clarify the question of whether people have a tend to use one of the right and left hemispheres of their innate brains dominantly, has explained that people have certain cognitive abilities but have strengths and weaknesses when they are born. In this regard, he has stated that the tendencies of people to use their natural abilities dominantly in the right and left hemisphere will shape over time (Ersoy \& Kartal, 2012). Although progress has been made in clinical studies based on many findings, important data on the functional asymmetry of the hemispheres of the brain have been clarified through "discrete brain studies".

Discrete brain study performed on epilepsy patients with severe seizures is one of them. The decrease in seizures after the formation of the tumor in "Corpus callosum" which connects the two hemispheres of the patients, activated the brain surgeons. Then the surgeons cut the Corpus callosum of these patients and divided into two hemispheres of the patients' brain (Wagenen \& Herren, 1940). As a result of these studies about patients, special test techniques have been developed to examine functional functions of two separated hemispheres. As a result of the studies carried out with the test techniques developed, the concept of lateralization, which means that the warnings are only affected by the related brain hemisphere, has been developed. That is, a warning affects only one brain hemisphere and the other brain hemisphere does not respond to this stimulus (Gundogan, 2005).

After the emergence of the concept of lateralization, the functional functions of discrete brain hemispheres were examined separately. Özeren (2002) defined the hemispheric dominance of brain hemispheres with different functions as one of the hemispheres of the brain was dominant than the other. There are two types of the dominance of brain hemispheres: standard and mixed. We can define standard dominance as right-hand use and left hemisphere dominance as both commonly seen in society. The use of the left hand and the dominance of the right brain hemisphere in the society is another of the standard dominance (Özeren, 2002; Öztan, 2006).

Our emotions, which are managed by brain functions which are considered to be a necessity in every period of our live and which are related to directing our behaviors, give us some warnings according to the situation we are in. While these warnings sometimes motivate us to reach the target, they sometimes send signals to us through our brains to get away from the situation we are in or to address (Frijda, 1986).

Many people understand that they cannot realize exactly how they feel. There is considerable amount of these people in society. In addition, the fact that people realize their emotions does not mean that they can express them verbally. If people are having trouble expressing the emotions they notice, there is a problem at this point. According to the neurophysiological approach of Papez's Theory of Emotion, based on the psychosomatic phenomenon of Ruesch and McLean, the lack of emotional satisfaction of the most basic needs corresponds to several responses. This is due to the connection break between the neocortex, which forms the outermost layer of 
the brain hemisphere, and the Hippocampus within the limbic system, where our emotions are controlled. Consequently, the emotions that are formed and controlled by the limbic system cannot reach the neocortex. Therefore, the individual who cannot verbalize his emotions expresses this situation in which he is involuntarily with bodily reactions. This situation is seen as a personality problem. In other words, it is defined as "alexithymia", a personality problem in which people have difficulty in noticing and expressing their feelings, and thinking introspected, but in reflecting that they adopt more extrovert thinking style (cognitive thinking towards external adaptation) (Way et al., 2007, p. 132; Hoppe \& Bogen, 1977; TenHoughten, Hoppe, Bogen, \& Walter, 1985, 1986; TenHoughten et al., 1987; Ruesch, 1948; McLean, 1949; Lesser, 1986).

The concept of alexithymia, which was started to be formulated by Nemiah and Sifneos in the early 1970s, was first used by Sifneos in 1972 to identify patients who were aware of or experienced these emotions, but who had difficulty in making sense of and expressing those feelings they felt (Taylor, 1984; Parker et al., 1998; Taylor \& Sifneos, 1998). This concept was later adapted to the language of Dereboy (1990) "absence of words for emotions" and emphasized that alexithymia was not a disease, but a personality characteristic. Şahin (1991) suggested the use of the term "emotionally deaf-and-dumb" for alexithymia, while it was not only limited to being "mute" to emotions but also emphasizing that those people are "deaf" to their own feelings. Dökmen (2000) chose to describe alexithymia as "thought slavery". The alexithymia used as a term for psychosomatic diseases has been understood to be a personality characteristic of the general population by determining that it can be seen in healthy individuals in later studies (Helmes et al., 2008; Taylor, 1984). In this regard, emphasized that the prevalence of alexithymia in healthy individuals might vary between $7 \%$ and $28 \%$ and that high alexithymia scores in individuals might be another factor in the disability (Luzumlu, 2013). The complexity of meaning arising from definitions and approaches in the literature related to the concept of alexithymia has also led to differences in the identification of the characteristics of individuals with alexithymia. The concept of alexithymia, defined and used by Sifneos for the first time in 1972, was likewise tried to be reconciled with it by several personality traits. Sifneos expressed that the most prominent feature for alexithymic individuals was to realize their feelings but had difficulty expressing their feelings. In other words, when these people take their feelings into the center of their lives, they give the impression that they have come from a different planet. In addition to this, it is observed that they are the people who can establish social relationships easily in their daily lives and can express themselves, but they have difficulties in establishing and distinguishing their feelings and thoughts and transferring these feelings and thoughts to the other side. These people are usually intelligent. However, they use their intelligence to escape their emotions (Sifneos, 1988). Taylor (1991), who suggested that it may have been right to define individuals with alexithymia in categories, have grouped individuals in four different categories. These are classified as: difficulty in recognizing, distinguishing, and expressing feelings; limitation in imagination, dream, and fantasy; work-oriented operational thinking; extrovert thinking (cognitive structure towards adaptation to external center). Although there are four main characteristics observed in individuals with alexithymia, Freyberger (1977) stated that as a result of his observations and researches, alexithymia can be seen in two ways: continuous (primary) and temporary and persistent (secondary) features. The primary features here are the reflection of long-term personality traits seen in psychosomatic patients and manifested by bodily complaints. Secondary features are seen as a temporary or permanent defense mechanism that manifests itself as a sudden trauma, either under stress or as a result of a sad incident. At this point, among the primary and secondary features observed in individuals with alexithymia, the points that draw attention from the research point of view are that "they adopt the style of work-oriented and extrovert thinking" and "they can exhibit narcissistic, psychosomatic, passive, aggressive or passive-dependent personality characteristics". Although there are many alexithymic personality traits, primary and secondary, it is not correct to say that alexithymia is present or not by looking at these characteristics. It would be more appropriate to mention the level of alexithymia in this regard. In addition, the main thing is the continuity of this process when these features are evaluated. In other words, it needs to be well analyzed that the occurrence and persistence of these physical complaints is a permanent condition or a temporary condition resulting from any trauma or bodily discomfort (Taylor, 1984; Krystal, 1979; Krystal, 1982; Sifneos, 1988).

\subsection{Adventure Recreation and Risk Taking}

Some participants have an increasing interest in leisure activities that have a high degree of excitement in relation to our behaviors and personality traits. The common feature of these activities is the presence of a high-risk of disability or death, and therefore such activities are called high-risk activities or adventure events (Guszkowska \& Boldak, 2010). The individual considers the high-risk content as part of the activity and therefore adopts the risk of death and disability (Breivik, 1999; Guszkowska \& Boldak, 2010). The adventure, defined as a "humanitarian need" that reflects a mood in the realization of such activities, is an atmosphere, a 
climate approach. "The adventure is the people's desire to see the other side of the mountain, and we are eager to break our ties with the ordinary and sail to the larger seas" (Rajola \& O'Kefe, 1999; Howard, 2009). For such activities, which are part of high-risk and adventure recreation programs, participants are looking for a strong feeling at the expense of risking their lives. High-risk activities were described as extra-ability, courage, and health-enhancing sports activities and stated that participation in such sports requires the ability to cope with environmental challenges, enforce mental boundaries, and balance emotions (Muszkieta \& Gembiak, 2004; Guszkowska \& Boldak, 2010). The risk, which is posed by the presence of danger and the potential for loss of valuables, is considered one of the main reasons that lead to activities in adventure programs in recreation and is confronted as the most remarkable situational variable in terms of outdoor advanture activities (Dinç, 2006, 2018).

The risk, which can be defined as a daily part of human life, is at the heart of the adventure as experience and satisfaction, and there may be a decrease in the willingness to participate in adventure recreation programs if there is no risk. The risk is often considered to be equivalent to the risk of death or serious injury, and the risk involved in the center of experience and satisfaction, and the lack of risk in this context may reduce the satisfaction that participants can get in the adventure (Weber, 2001; Dickson \& Dolnicor, 2004).

The "risk perception" in an adventure is individual. Risk varies from individual to individual, not only physical risks but also social and psychological risks are possible stated that sometimes an individual perceives the activity as a risk, and sometimes perceives moving with a group is a risk. In addition, participants do not consider adventure as a high-risk factor, and individuals consider risk as a part of the experience and consider it as a combination of fear, excitement, seeking and shiver (Dickson \& Dolnicor, 2004). On the other hand, there is nothing clear about why people still tend to take risks against the resistance of the organism in high-risk outdoor activities within the adventure recreation (Dinç, 2006, 2018). Guszkowska and Boldak (2010), who stated that there are different determinants of this situation observed in the participants in adventure recreation and explanations about the concept of risk and adventure, expressed that stimulant and behavioral needs being appeared in connection with this determined by genes, and that Monamine Oxidase Enzyme (MAO) has been found as a biological determinant in the search for excitement in most research (Gostkowska \& Boldak, 2010). So indeed, avoidance of harm (avoidance of risk), searching for innovation and excitement is our genetic heritage and are determined by the levels of MAO neurotransmitters (Monasterio, 2007). As a biological determinant of the search for excitement, this enzyme is responsible for the destruction and inactivation of dopamine particles that drive people to become active. High levels of dopamine and serotonin, which are chemicals that provide important information transfer between the lower and upper brain regions, have been proven to be helpful in high-risk activities (Monasterio, 2007). High levels of MAO production leads people to be more passive and less sensitive to risk-taking behavior. In other words, the individual tends to take lower risks and makes himself more inactive for the risk-taking behavior (Guszkowska \& Boldak, 2010). On the other hand, psychologists attributed this to personal characteristics and stated that personal characteristics that differ among individuals could create a tendency to take risks. This situation is stated as a tendency to participate in activities that are inherently hazardous and defined as "risk-taking feature", tendency to seek and find stress-inducing situations and participate in all kinds of purposeful actions that cause enough danger or strange changes to create anxiety in many people (Pizam et al., 2004).

Summarizing the interesting research findings on risk-taking behavior, it is not surprising that high-risk sports, such as mountaineering and parachuting, are associated with significant risk of accidents and death. It will help to explain the fact that people who choose such sports with high-risk content have a different biological structure than the average people in society, and also help to explain why differences in brain chemistry are the factors in turning to such dangerous sports (Monasterio, 2007).The individual tends to take more risks if a difference occurs between the goals of the individual and the situation that the individual in, according to the theory of risk sensitivity (Mishra \& Lalumière, 2010, pp. 605-611). Psychological research has brought a different approach to the subject and reconcile all behaviors with the increase of the send of self. Some studies suggest that people who take high levels of risk as individual features are more prone to sensation seeking (Dinç, 2006, 2018).

While the need for stimulation, excitement, and adventure explains to a certain extent why thrill seekers participate in sporting activities, Zuckerman's sensation seeking model does not fully explain to us how high-risk individuals perceive the risk of injury or death during activities (Zuckerman, 2007).

\subsection{Alexithymia-Narcissistic Personality and Risk Taking}

Different assumptions were made as a result of the studies of experts studying the neuro-physiological approach regarding the risk taking. While neuro-physiology experts suggested that there was a relationship between brain 
hemispheres and alexithymic features (Koçak, 2003); Lesser (1981), Sifneos (1988), Taylor (1991) suggested that individuals with alexithymic features may exhibit narcissistic, psychosomatic, passive, aggressive, or passive-dependent personality characteristics, and that they are more dependent on out and are individuals who prefer to be alone, and that these characteristics are the second most important traits that frequently exist in such individuals. Researchers, who approached the subject from a different perspective after this explanation made by the authors for alexithymic individuals, have conducted many studies, by assuming that the narcissistic personality trait would create a tendency to take risks in the individual. These surveys include specific risk activities such as gambling (Laskey et al., 2008), aggressive driving (Britt \& Garitty, 2006), financial investment strategies (Foster et al., 2007), sensation seeking (Emmons, 19810), and impulses (Foster \& Trimm, 2008; Vazire \& Funder, 2006). While the research aimed to reveal the tendency of the narcissists, Lakey focused on the causes of why narcissists take more risk than the other people in his study carried out in 2008 and he became one of the researchers who conduct an exceptional study on this subject. In his study on gambling related to this subject, Lakey noted that narcissists were aware of the results of the risk, but were motivated to take risks because they were hypersensitive to the rewards; and he stated that there was a relationship between narcissistic personality trait and risk-taking tendency, and individuals with traits tend to take more risks than others (Foster et al., 2009).

\subsection{Hypothesis and Research Questions}

In high-risk adventure recreation activities, there is still no clear explanation of why participants tend to take risks against the resistance of the organism. It is known that narcissistic personality features are among the second-degree traits observed in individuals with alexithymia and that the concept of alexithymia is seen as long-term, temporary or permanent personality traits that continue to be widespread in the normal population. In this context, it is aimed to examine the relationship between the dominant brain areas, alexithymia and risk-taking behaviors in outdoor adventure with the idea that the related concepts can answer the questions about the risk-taking behavior within outdoor adventure programs.

The analysis of the data provides answers to questions:

$>$ Do the independent variable (brain dominance) have an effect on the mediator variable (alexithymia, extrovert thinking).

$>$ Do the mediator variable (alexithymia, extrovert thinking) have an effect on the dependent variable (risk-taking behavior).

$>$ Do the independent variable (brain dominance) have an effect on the dependent variable (risk-taking behavior).

If the mediator variable (alexithymia, extrovert thinking) is included in the analysis together with the independent variable (brain dominance), is the effect of the independent variable (brain dominance) on the dependent variable (risk-taking behavior) reduced or eliminated completely?

\section{Method}

\subsection{Participants}

The study was carried out on 652 (female $158 \mathrm{M}$ age $=34.59$, sd=9.93 years; male $494 \mathrm{M}$ age $=34.69$, $\mathrm{sd}=9.41$ years) participants that were selected using the cluster sampling method in different categories (air, land, water advanture activities) between the years 2016-2017.

\subsection{Data Collection Instrument}

\subsubsection{Personal Information Form}

The form was used to determine the demographic information that contain gender, age, educational status, dominant hand, activity, experience period, frequency of activity, etc. were asked.

\subsubsection{TAS-20 (Toronto Alexithymia Scale)}

It has developed by Bagby, Taylor and Parker (1994) with 20 item and adapted to Turkish by Güleç at al. (2009). The reliability coefficients of the scale in the present study were $\alpha=0.76$ for the total, $\alpha=0.74$ for "difficulty in defining emotions", $\alpha=0.65$ for "emotion expression", $\alpha=0.61$ for the "extrovert thinking" sub-dimensions.

\subsubsection{Brain Dominance Instrument}

It was developed by Davis et al. (1994) and adapted to Turkish by Avcı (2007) with 26 items. The reliability coefficient of the scale was 0.70 . 


\subsubsection{A Domain-Specific Risk-Taking (DOSPERT)}

It was developed by Weber et al. (2002) then revised by Blais and Weber (2006) with 30-item short form and adapted to Turkish by Yavaş Tez and Dinç (2017) with 25 items, 5 sub-scales. The reliability coefficients of the scale in the present study were $\alpha=.86$ for total, $\alpha=.78$ for ethical, $\alpha=.78$ for financial $.78, \alpha=.76$ for health/safety, $\alpha=.78$ for recreational, $\alpha=.75$ for social sub-diamention.

\subsection{Data Collection}

All scales were transferred to the electronic environment in order to reach the target audience in the research and scale forms were applied via the forums, groups and social media related to outdoor advanture activities. In addition, the scale forms were delivered to them by e-mail and cargo by contacting the coaches who voluntarily wish to apply the scale forms to the athletes within their organization. At the end of the data collection phase, a total of 690 participants were reached and 652 were completed without error, were entered to analysis.

\subsection{Istatistics and Data Analysis}

IBM SPSS Statistics 20 package program was used for statistical analysis. the parametric tests are preferred by determining that the normal distribution deviation of the data was nonsense at Kolmogorov-Smirnov/Shapiro-Wilk and Leverne Test $(p>.05)$. Pearson Moment Correlation coefficient was examined to determine the relationship between the scales and the sub-dimensions. The mediator influence analysis method formed by Baron and Kenny $(1986,1176)$ to determine the influence is based. This effect detection was made using stepwise hierarchical modeling for Multiple Linear Regression Analysis. The resulting significance was evaluated by the "Sobel Test" method. In this regard, the prerequisites must be fulfilled in order to use this method of analysis created by Baron and Kenny. If these conditions are not provided, it is not possible to mention the mediation influence. These conditions are incorporated and listed below for the research.

If the significance, ensued after the analysis performed with the fulfillment of these conditions, was removed completely, it indicates the existence of "full mediation" relationship; only if there was a decline in the degree of relationship it shows the existence of "partial mediation" relationship. However, it is stated that the "Sobel Test" method must be used in order to determine whether the significance of this point is a true significance or not (Baron \& Kenny, 1986). Frazer, Tickets, and Barron (2004, p. 128) stated that it was accepted literally the existence of mediator influence in the case that Z-score coefficient is greater than $+/-1.96$ and statistically significant $(\mathrm{p}<.05)$ concerning the significance of "Sobel Test".

\section{Result}

First, the correlation coefficients between the variables were examined before the mediator effect analysis steps. A statistically significant relationship was found between dominant brain areas and alexithymia levels (r: .154; $\mathrm{p}$ $<.01$ ); between alexithymia levels and risk-taking behavior levels (r: .120; $<<.01)$; between dominant brain areas and risk-taking behavior levels (r: .195; $\mathrm{p}<.01)$ as can be seen in Table 1.

Table 1. An investigation of the relationship between the dominant brain areas, Alexithymia levels, and risk-taking behavior levels of adventure participants in terms of scale total scores (Pearson Correlation Analysis Results)

\begin{tabular}{|c|c|c|c|}
\hline & & Brain Dominance & Alexithymia \\
\hline Brain Dominance & $\mathrm{r}$ & 1 & \\
\hline Alexithymia & $\mathrm{r}$ & $.154^{* *}$ & 1 \\
\hline & $\mathrm{p}$ & .000 & \\
\hline & & Alexithymia & Risk Taking \\
\hline Alexithymia & r & 1 & \\
\hline Risk Taking & $\mathrm{r}$ & $.120 * *$ & 1 \\
\hline & $\mathrm{p}$ & .000 & \\
\hline & & Risk Taking & Brain Dominance \\
\hline Risk Taking & $\mathrm{r}$ & 1 & \\
\hline Brain Dominance & $\mathrm{r}$ & $.195^{* *}$ & 1 \\
\hline & $\mathrm{p}$ & .000 & \\
\hline
\end{tabular}

Note. ${ }^{* *} \mathrm{p}<.01$.

Secondly, whether the effect of brain pressure and alexithymia on risk-taking behavior was investigated by "Simple Linear Regression Analysis". The results of the analysis are presented below: 
Table 2. The results of simple linear regression analysis for examining the level of impact between the dominant brain areas and the risk-taking behavior levels of the participants of outdoor adventure recreation

\begin{tabular}{|c|c|c|c|c|c|c|}
\hline \multirow[b]{3}{*}{ VARIABLES } & \multirow{2}{*}{$\begin{array}{l}\text { Standardized Coefficients } \\
\text { Beta }(\beta)\end{array}$} & \multicolumn{2}{|c|}{ Unstandardized Beta Coefficient } & \multirow[b]{3}{*}{$\mathrm{T}$} & \multirow[b]{3}{*}{$\mathrm{p}$} & \multirow[b]{3}{*}{$\mathrm{R}^{2}$} \\
\hline & & Standard Error & $\mathrm{B}$ & & & \\
\hline & & & & & & \\
\hline Alexithymia & .95 & .02 & 1.87 & 81.91 & .00 & .91 \\
\hline Extrovert thinking & .95 & .04 & 3.99 & 82.86 & .00 & .91 \\
\hline Brain Dominance & -.11 & .82 & -2.48 & -3.00 & .00 & .016 \\
\hline
\end{tabular}

The results of simple linear regression analysis in Table 2 showed that alexithymia had a statistically significant influence on risk-taking behavior $(\beta=.95, \mathrm{t}=81.91, \mathrm{p}=.00)$. Similarly, it was found that the sub-dimension of extrover thinking, one of the sub-dimensions of alexithymia, had a statistically significant influence on the risk-taking behavior $(\beta=.95, \mathrm{t}=82.86, \mathrm{p}=.00)$. On the other hand, it was found that brain dominance had a statistically significant influence on risk-taking behavior $(\beta=-.11, \mathrm{t}=-3.00 \mathrm{p}=.00)$. When this situation is evaluated, it is noted that all variables have an influence on the risk-taking behavior, but their effect levels differ. While alexithymia and extrovert thinking accounted for $91 \%$ of risk-taking behavior; brain dominance explains only $0.16 \%$ of the risk-taking behavior. This has provided the basis for the mediator influences of alexithymia and extrovert thinking on risk-taking behavior. In this direction, new hypotheses have been established in the research as "There is a mediating influence of alexithymia between dominant brain areas and risk-taking behaviors of outdoor adventure recreation participants" and "There is a mediating influence of extrovert thinking between dominant brain areas and risk-taking behavior levels of participants of outdoor adventure recreation". In the hypotheses, "alexithymia and extrovert thought" variables were considered as determinants of risk-taking behavior and "mediator influence" was tested. In other words, it is thought that brain dominance may cause alexithymia, that the extrovert personality characteristics, one of the alexithymic personality traits may cause risk-taking behavior. Here, the effect of brain dominance and risk-taking behavior is indirect. Alexithymia and extrovert thinking act as mediators. In this respect, in order to determine whether alexithymia and extrovert thinking play a mediating role in the relationship between brain dominance and risk-taking behavior, it is based on the mediator influence analysis method presented by Baron and Kenny (1986).

It was determined as "brain dominance" for the independent variable of the study; as the "risk-taking behavior level" for the dependent variable; as "extrovert thinking", which is one of the alexithymia total scores and alexithymic sub-dimensions, for mediator variables to perform in Stepwise Regression Analysis. The results of the analysis performed in this direction are as follows:

In Stepwise Regression Analysis performed in Table 3, firstly "brain dominance total score", secondly "alexithymia total score", and finally "extrovert thought subdimension total score" were entered into the model. In the second phase of the stepwise regression analysis, when the results of the stepwise regression model are examined, the influence of "brain dominance" variable on risk-taking behavior $(\beta=.00, \mathrm{t}=.80, \mathrm{p}=.42)$ was eliminated with the inclusion of the variable "alexithymia".

Table 3. Test results of stepwise regression analysis of multiple linear regression analysis to investigate the influence of alexithymia and extrovert thought between the dominant brain areas and risk-taking behavior of adventurer

\begin{tabular}{|c|c|c|c|c|c|c|}
\hline \multirow[t]{3}{*}{ MODELS } & \multirow{3}{*}{$\begin{array}{l}\text { Standardized Coefficients } \\
\text { Beta }(\beta)\end{array}$} & \multicolumn{2}{|c|}{ Unstandardized Beta Coefficient } & \multirow[b]{3}{*}{$\mathrm{T}$} & \multirow[b]{3}{*}{$\mathrm{P}$} & \multirow[b]{3}{*}{$\mathrm{R}^{2}$} \\
\hline & & Standart Error & $\mathrm{B}$ & & & \\
\hline & & & & & & \\
\hline \multicolumn{7}{|c|}{ THE FIRST MODEL } \\
\hline Brain Dominant & -.11 & .82 & -2.48 & -3.00 & .00 & .016 \\
\hline \multicolumn{7}{|c|}{ THE SECOND MODEL } \\
\hline Brain Dominant & .00 & .25 & .20 & .80 & .42 & .91 \\
\hline Alexithymia & .95 & .02 & 1.88 & 81.28 & .00 & \\
\hline \multicolumn{7}{|c|}{ THE THIRD MODEL } \\
\hline Brain Dominant & .02 & .24 & .43 & 1.82 & .06 & .92 \\
\hline Alexithymia & .43 & .12 & .86 & 6.76 & .00 & \\
\hline Extrovert Tinking & .52 & .27 & 2.20 & 8.14 & .00 & \\
\hline
\end{tabular}


On the other hand, it was observed that in the third phase of the analysis, the inclusion of the "extrovert thought" variant of the model did not change the influence of the "brain dominance" variable on the risk-taking behavior $(\beta=.02, t=1.82, p=.06)$. These findings have pointed out that in general, the influence of brain dominance and risk-taking behavior could be the full mediation influence of alexithymia and extrovert thought. The existence of the resulting significance was decided by the "Sobel Test" method.

Table 4. Sobel test results on control of the significance of the mediating influence of alexithymia and extrovert thought between dominant brain areas and risk-taking behavior levels of outdoor adventurer

Sobel Test Results of Model-2

\begin{tabular}{|c|c|c|c|c|c|}
\hline \multicolumn{2}{|c|}{$\begin{array}{l}\text { Unstandardized Regression Coefficient and } \\
\text { Standart Error }\end{array}$} & \multicolumn{2}{|l|}{ Z-Coefficient } & Standart Error & P-Value \\
\hline $\mathrm{a}$ & -2.483 & Sobel Test & -3.0040 & 1.55447 & 0.00 \\
\hline $\mathrm{b}$ & 1.881 & Aroian Test & -3.0038 & 1.55448 & 0.00 \\
\hline $\mathrm{s}_{\mathrm{a}}$ & .826 & Goodman Test & -3.0042 & 1.55446 & 0.00 \\
\hline $\mathrm{s}_{\mathrm{b}}$ & .023 & & & & \\
\hline
\end{tabular}

Sobel Test Results of Model-3

\begin{tabular}{|c|c|c|c|c|c|}
\hline \multicolumn{2}{|c|}{$\begin{array}{l}\text { Unstandardized Regression Coefficient and } \\
\text { Standart Error }\end{array}$} & \multicolumn{2}{|l|}{ Z-Coefficient } & Standart Error & P-Value \\
\hline $\mathrm{a}$ & -2.483 & Sobel Test & -2.819 & 1.9424 & 0.00 \\
\hline $\mathrm{b}$ & 2.206 & Aroian Test & -2.801 & 1.9552 & 0.00 \\
\hline $\mathrm{s}_{\mathrm{a}}$ & .826 & Goodman Test & -2.838 & 1.9294 & 0.00 \\
\hline $\mathrm{s}_{\mathrm{b}}$ & .271 & & & & \\
\hline
\end{tabular}

However, whether the full mediation influence of alexithymia and extrovert thought depended on the significance level of the decrease in Beta value, the testing of this level of significance was carried out through the "Sobel test". At this point, unstandardized (uncorrected) regression coefficients $(\mathrm{a}, \mathrm{b})$ and their standard error values $\left(\mathrm{s}_{\mathrm{a}}, \mathrm{s}_{\mathrm{b}}\right)$ belonging to the relevant variables in the research are entered into a calculation program that is offered online via the internet, and the "Sobel Test" was carried out. It was concluded that the effect of alexithymia and extrovert thinking on brain dominance and its influence on risk-taking behavior has a full mediating effect due to the fact that according to the test results, Sobel, Aroian and Goodman tests were significant (respectively, $Z=-3.00 ;-3.00 ;-3.00 ; \mathrm{p}<.01$ for Model 2; $Z=-2.81 ;-2.80 ; 2.83 ; \mathrm{p}<.01$ for Model 3). This is explained by the fact that, for the second model, the explainability of alexithymia to have a full mediator effect between brain dominance and risk-taking behavior is $91 \%$; the explainability of extrovert thought is $92 \%$.

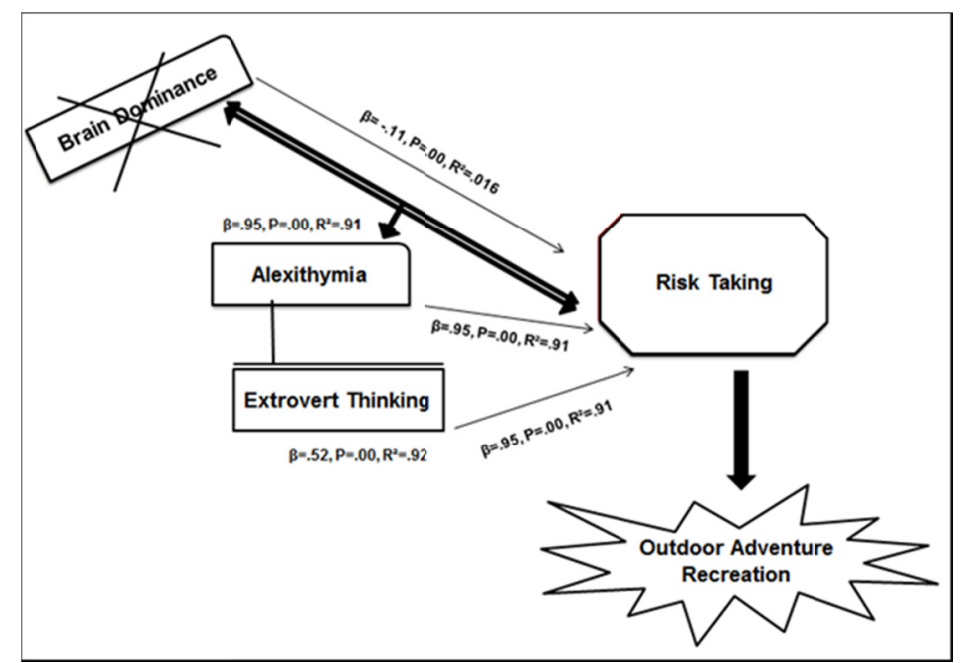

Figure 1. The influence and mediator effect model on the results of simple and multiple linear regression (stepwise) analysis for hypotheses established with brain dominance, alexithymia, and extrovert thought variables 
In line with the main objective of the research, it has been seen that alexithymia and extrovert thought significantly predicts the risk-taking behavior. Although brain dominance is known as the etiology of alexithymia, it has been observed that the effect of brain dominance on risk-taking behavior has been eliminated with the inclusion of alexithymia as a mediator variable, although it is considered as a factor in direct risk-taking behavior. However, it has been determined that the alexithymia and the extrovert thought, one of the sub-dimensions of alexithymia has a full mediator role between the brain dominance and the risk-taking behavior, but their explainability is determined to vary and it has been concluded that extrovert thought reflection explains the risk-taking behavior at a higher rate $(92 \%)$.

\section{Discussion}

In the literature, different studies have been carried out as individual or binary variables in the areas of psychology, medicine, sports etc. related to brain dominance, alexithymia, brain dominance and alexithymia, risk-taking behavior. When the national and international literature is examined; in the meta-analysis study carried out on the structural differences of the male and female brain by Ruigrok et al. (2014), the limbic system, known as the center of the emotion of our brain, is observed to be greater in women than in males. In addition, it has been reported by researchers that the ability of women to express their feelings to the opposite side is higher than men; that the limbic system responsible for the emotional area of our brain is larger, and therefore women can connect more emotionally than men (Selçuk, 1989; Arıkan, 2011).

The amygdala, known as one of the areas responsible for the formation and expression of emotions, is more left-lateralized, and it has been reported that the amygdala reacts violently because people reflect the outward-looking way of thinking with a happy face expression (Live, Silvers, Whitfield, Gotlib, \& Gabrieli, 2002 , p. 296). In addition, the response of amygdala to an emotional stimulus in women and men is more associated with the left hemisphere of the brain and lateralized to the left, and the weight of the left in women has been found to be more dominant. This also makes a difference in the way men and women process emotions. Women's memories are more retentive than men, and it is therefore very easy for them to remember emotions. (Wager, Phan et al., 2003; Eşel, 2005). Some researchers have reported that the women's Corpus Callosum, which connects brain hemispheres is thicker than men, and that the connection between the right and left hemisphere of women is 30\% higher (Dubb, Gur et al., 2003; Hwang, Lee et al., 2004). It is suggested that the excess amount of dopamine in the brain is associated with estrogen hormone (Becker, 1999, pp. 803-812). It has been reported that the amount of dopamine in the brain decreases with the men get older but there is no change in women (Laakso, Vilkman et al., 2002).

In studies investigating the relationship between brain dominance and alexithymia, researchers reported that emotional information in the right brain hemisphere could not be verbalized by the left brain hemisphere with the breakdown of the connection between the two brain hemispheres and that similar mechanisms were seen in individuals with alexithymia and the same problems could be experienced for them (Hoppe \& Bogen, 1977; TenHoughten, Hoppe, Bogen, \& Walter, 1985, 1986; TenHoughten, Walter, Hoppe, \& Bogen, 1987). When the studies about the differences in terms of alexithymia and gender were examined, while some studies could not find any difference (Batıgün \& Büyükşahin, 2008); Mattila et al. reported that men had more alexithymic features in 2006 (Mattila, Salminen, Nummii, \& Joukamaa, 2006); in a study conducted by Blanchard et al. (1981), $1.8 \%$ of female students and $8.2 \%$ of male students showed alexithymic characteristics. In addition, Cooper and Halmstrom (1984) found that more alexithymic properties were seen in women than males. In the study of the relationship between hand preference of individuals and alexithymia, it was reported that the right-hand users had more alexithymic characteristics (Taylor, Bagby, \& Parker, 1991); and only the right-hand users had more alexithymic characteristics than those who used the left hand or both hands equally (Fricchione \& Howanitz, 1985, pp. 156-169). In the studies carried out by various researchers, it was found that men exhibited more alexithymic properties than women and this was associated with the feeling that men are under pressure. It has been stated that men are under pressure in society when compared to women and that expressing of their feeling is considered as weak by their environment, and these would cause men not to express their feelings comfortably and because of this reason that they cannot develop a vocabulary set (Levant, Halter, Hayden, \& Williams, 2009; Levant, Good, Cook, O’Neill Smalley, \& Owen, 2006). It is observed that there are differences between age and alexithymia. While in some studies (Paulson, 1985; Krystal, Güler, \& Cichetti, 1986 ) it is revealed the evidence that alexithymia varies by age; in some studies, (Karakis \& Levant, 2012), it was concluded that alexithymia has no relation with age.

When studies on differences between gender differences and risk-taking behavior have been examined, men have been reported to take more risks in general than women (Arnett, 1992; Arnett \& Balle-Jense, 1993; Parsons, Siegel, \& Cousins, 1997; Paetsch \& Bertrand, 1997; Chen, Greenberger, Lester, Dong, \& Guo, 1998; Byrnes, Miller, \& 
Schafer, 1999; Grenee, Krcmar, Walters, Rubin, \& Hale, 2000; Yılmaz, 2000; Aktaş 2014; Harris \& Jenkins, 2006).

Pedersen (1977), who studied the relationship between activity preference and risk-taking behavior, while observed that high-risk activities such as sky diving, cliff jumping, hang gliding, and motorcycle racing; The lowest risk activity was reported to be underwater diving. Demirhan (2003) reported that with a similar study, respectively the riskiest activities were high mountain climbing, rock climbing, touring ski, snowboarding, cross-country skiing, and downhill skiing.

In studies on individual differences, personality traits and risk-taking behavior; It has been stated that most of the active rock climbers display a tendency of high risk-taking behavior and that the self-sufficiency is a factor in the tendency to take risks in the individual (Llewellyn \& Sanchez, 2008; Llewellyn et al, 2008). While Mishra and Lalumiere (2011) express that personality traits such as impulsivity, sensation seeking and low self-control are associated with risk-taking behavior; Slanger and Rudestam (1997) identified a relationship between the sensation seeking and the risk-taking behavior increased in directly proportional but there was no relationship between risk-taking behavior and sensation seeking. In studies, researching the relationship between the between narcissistic personality traits and risk-taking behavior, especially on gambling (Lakey, Rose, Campbell, \& Goodie 2008), aggressive driving (Britt \& Garitty, 2006), financial investment strategies (Foster, Mishra, \& Reidy, 2007), sensation seeking (Emmons, 1981), impulsivity (Foster \& Trimm, 2008; Vazire \& Funder, 2006; Foster, Shenesey, \& Goff, 2009), it couldn't find any difference between participants with narcissistic and non-narcissistic personality related to the risk-taking behavior under normal circumstances. However, when the "reward" factor is included, the participants with narcissistic personality are extremely fond of the awards, thus triggering their tendency to take risks.

The studies carried out in different fields are summarized in the literature. When the studies are examined, it is observed that there is no study examining the relationship between brain dominance, alexithymia, and risk-taking behavior. In the present study, it has been found that alexithymia total score and extrovert thinking, which is one of the sub-dimensions of alexithymia, have a fully mediated role in the relationship between brain dominance and risk-taking behavior. When the findings obtained in the study are evaluated, it is concluded that the participants of outdoor adventure recreation with a high level of alexithymia and extrovert personality have a higher tendency to take the risk. The results are thought to fill an important gap in discussions on "risk-taking behavior", which is considered as the main variable that directs individuals to act in adventure recreation.

The current research has been advanced and completed in accordance with certain limitations, increasing the sample size and type of activities for future. It should also be taken into consideration that the risk perception is individual and varies according to the characteristics and experience of the participants. In this respect, research can be carried out with participants with high and low experience related to the activity. The study has been conducted using only quantitative research methods. At this point, it is thought that it will be useful to support future studies with qualitative data.

\section{Acknowledgments}

Any grants or other financial support was not received for our study. I assert that written informed consent was taken from participants for reporting the results. The manuscript is original work of both authors and each made a significant contribution on this study. None of the writers is the person's routinely involved in the review and acceptance of manuscripts peer reviewers and editors associate editors, and consulting editors of the journal. I confirm that this manuscript has not been published elsewhere nor is it currently under consideration for publication in any other journal. I affirmed that both authors have read and approved the final version of the manuscript. The study taken by the ethics committee permits includes part of a master's thesis. Some parts of the study were presented verbally in International Congress on Recreation and Sport Management at the date of 1013 May 2018 in Antalya/Turkey

\section{References}

Aktaş, I. (2014). The Evaluation of Self Esteem and Risk-Taking Levels in Subjects Nonsporting and Sporting in Different Branches. Atatürk Üniversity, Institute of Health Sciences, Master Thesis, Erzurum, 1-74.

Arıkan, R. N. (2011). Female Brains Male Brains, Kaynak. Retrieved from http://www.milliyet.com.tr/uzm-psikolog-psikoterapist-rusen-nur-arikan/kadin-beyni-erkek-beyni-kadin-13 $43245 /$

Arnett, J., \& Balle-Jensen, L. (1993). Cultural Bases Bases of Risk Behavior: Danish Adolescent. Child Development, 64, 1842-1855. https://doi.org/10.2307/1131473 
Arnett, J. (1992). Socializition and Adolescent Reckless Behavior: A Reply to Jessor. Developmental Rewiew, 12, 391-409. https://doi.org/10.1016/0273-2297(92)90015-T

Bagby, R. M., Parker, J. D. A., \& Taylor, G. J. (1994). The Twenty-Item Toronto Alexithymia Scale-I Item Selection and Cross Validation of the Factor Structure. $J$ Psychosom Res., 38, 23-32. https://doi.org/10.1016/0022-3999(94)90005-1

Bagby, R. M., Taylor, G. J., \& Parker, J. D. A. (1994). The Twenty-Item Toronto Alexithymia Scale: II. Convergent, Discriminant and Concurrent Validity. $J$ Psychosom Res., 38, 33-40. https://doi.org/10.1016/0022-3999(94)90006-X

Baron, R. M., \& Kenny, D. A. (1986). The Moderator-Mediator Variable Distinction in Social Psychological Research: Conceptual, Strategic, and Statistical Considerations. Journal of Personality and Social Psychology, 51(6), 1173-1182. https://doi.org/10.1037/0022-3514.51.6.1173

Batıgün, A., \& Büyükşahin, A. (2008). Alexityhmia: Psychological Symptoms and Attachment Styles. J Clin Psy., 11(3), 105-114.

Blais, A., R. \& Weber E. U. (2006). A Domain-Specific Risk-Taking (DOSPERT) Scale for Adult Populations. Judgment and Decision Making, 1, 33-47. https://doi.org/10.1037/t13084-000

Blais, A. R., \& Weber, E. U. (2002). Testing Invariance in Risk Taking: A Comparison Between Anglophone and Francophone Groups. Scientific Series, 25, 1-28. https://doi.org/10.1037/t13084-000

Blanchard, B. E., Arena, J. G., \& Pallmeyer, J. P. (1981). Psychosometrik Properties of a Scale to Measure Alexithymia. Psychother Psychosom, 35, 67-71. https://doi.org/10.1159/000287479

Breivik, G. (1999). Sensation Seeking in Sport (pp. 45-68). Oslo: Norges Idrettshoegskole. https://doi.org/10.1016/0191-8869(83)90150-2

Britt, T., \& Garrity, M. J. (2006). Attributions and Personality as Predictors of the Road Rage Response. British Journal of Social Psychology, 45, 127-147. https://doi.org/10.1348/014466605X41355

Byrnes, J. P., Miller, D. C., \& Schafer, W. D. (1999). Gender Differences in Risk Taking: A Meta-Analysis. Psychology Bullettin, 125, 367-383. https://doi.org/10.1037/0033-2909.125.3.367

Canli, T., Silvers, H., Whitfield, S. L., Gotlib, I. H., \& Gabrieli, J. D. (2002). Amygdala Response to Happy Faces as A Function of Extraversion. Science, 296, 2191. https://doi.org/10.1126/science.1068749

Chen, C., Greenberger, E., Lester, J., Dong, Q., \& Guo, M. S. (1998). A Cross-Culturel Study of Family and Peer Correlates of Adolescent Misconduct. Developmental Psychology, 34, 770-781. https://doi.org/10.1037/0012-1649.34.4.770

Cooper, E. D., \& Holmstrom, R. W. (1984). Relationship Between Alexihmia and Somatic Complaints in Normal Sample. Psychother Psychosom, 41, 20-24. https://doi.org/10.1159/000287780

Davis, E. C., Nur, H., \& Ruru, S. A. (1994). Helping Teachers and Students Understand Learning Styles. English Teaching Forum, 32(3), 1-17.

Demirhan, G. (2003). Perception of Mountain Sports Risk. Gazi BESBD, VIII(3), 3-10.

Dereboy, F. (1990). Alexithymia: A Review. Turkish Journal of Psychiatry, 157.

Dickson, T., \& Dolnicor, S. (2004). No Risk, No Fun: The Role of Perceived Risk in Adventure Tourism. University of Wollongong. Research Online. Retrieved from http://ro.uow.edu.au/commpapers (1-11).

Dinç, S. C. (2006). Development A Scale of Outdoor Adventure Activity Leadership. Hacettepe University Institute of Healty Sciences, PhD Thesis in School of Sport Sciences and Technology, Ankara.

Dinç, S. C. (2018). Doğa Sporları Etkinliklerine İlişkin Liderlik Ölçeğinin Geliştirilmesi. Spor Yayınevi Kitapevi, Ankara.

Dökmen, Ü. (2000). Existence, Development, Reconciliation in The Process of Harmony with The Universe (pp. 1-39). Istanbul Publishing System.

Emmons, R. A. (1981). Relationship Between Narcissism and Sensation Seeking. Psychological Reports, 48, 247-250. https://doi.org/10.2466/pr0.1981.48.1.247

Ersoy, E., \& Kartal, Ö. (2012). Artificial Neural Networks and Human Brain. Journal of human and Social Sciences, 1(2), 1-18. 
Eşel, E. (2005). The Differences Between Male and Female Brains. Journal of Clinical Psychopharmacology, $15(3), 139$.

Freyberger, H. (1977). Supportive Psycho Therapeutic Techniques in Primary and Secondary Alexithymia. Psychotherapy Psychosomatic, 28, 337-342. https://doi.org/10.1159/000287080

Fricchione, G., \& Howanitz, E. (1985). Aprosodia and Alexithymia a Case Report. Pschotherapy Psychosomatics, 43, 156-169. https://doi.org/10.1159/000287873

Frijda, N. H. (1986). Theemotions (p. 71). Cambridge: Cambridge University Press.

Foster, J. D., \& Trimm IV, R. F. (2008). On Being Eager and Uninhibited: Narcissism and Approach-Avoidance Motivation. Personality and Social Psychology Bulletin, 34(7), 1004-1017. https://doi.org/10.1177/0146167208316688

Foster, J. D., Misra, T. A., \& Reidy, D. E. (2007). Narcissists Are Approach-Oriented Toward Their Money and Their Friends. Journal of Research in Personality. https://doi.org/10.1016/j.jrp.2009.05.005

Foster, J. D., Shenesey, J. W., \& Goff, J. S. (2009). Why Do Narcissists Take More Risk? Testing the Roles of Perceived Risks and Benefits of Risky Behaviors. Personality and Individual Differences, 47, 885-889. https://doi.org/10.1016/j.paid.2009.07.008

Greene, K., Krcmar, M., Walters, L. H., Rubin, D. L., \& Hale, L. (2000). Targeting Adolescent Risk-Taking Behaviors: The Contributions of Egocentrism and Sensation-Seeking. Journal of Adolescence, 23, 439-461. https://doi.org/10.1006/jado.2000.0330

Guszkowska, M., \& Boldak, A. (2010). Sensation Seeking in Males Involved in Recreation. High Risk Sports. Biology Sport, 27(3), 157-162. https://doi.org/10.5604/20831862.919331

Güleç, H., Köse, S., Güleç, M. Y., Çitak, S., Evren, C., Borckardt, J., \& Sayar, K. (2009). Rehability and Factorial Validity ff The Turkish Version of the 20-Item Toronto Alexithymia Scale (TAS-20). Clinics Psychopharmacological Bulletin, 19(3), 1-7.

Gündoğan, N. Ü. (2005). Öğrenme ve Davranışlarda Sol ve Sağ Beyin Yarım Kürelerinin Fonksiyonel Asimetrisinin Önemi (Laterizasyon). Ankara: Başkent Üniversitesi Tıp Fakültesi Fizyoloji A.D. Türkiye Klinikleri J. Med. Sci., 25, 225-231.

Harris, C. R., \& Jenkins, M. (2006). Gender Differences in Risk Assessment: Why Do Women Take Fewer Risk Than Men? Judgment and Decisions Making, 1(1), 48-63. doi: 20002-4242

Helmes, E., McNeill, P. D., Holden, R. R., \& Jackson C. (2008). The Constuct of Alexithymia: Associations with Defense Mechanism. Journal of Clinical Psychology, 64(3), 318-319. https://doi.org/10.1002/jclp.20461

Hoppe, K., \& Bogen, J. (1977). Alexithymia in Twelve Commissurotomized Patients. Psychotherapy and Psychosomatics, 148-155. https://doi.org/10.1159/000287057

Howard, R. A. (2009). A case study of the ottowa valley whitewater rafting Industry: standards and risk mangement. Brock Universiy. Submitted in Partial Fulfillment of the Requirements Forth He Degree of Master of Arts in Appired Health Sciences.

Jensen, E., (1998). Teaching with The Brain in Mind, Alexandra, Virginia Association for Supervision and Curriculum Development (2nd ed.). USA. ISBN 0-87120-299-9

Karabekiroğlu, K. (2008). Nicotinic Receptors, Nucleus Akumbens, And Attention Deficit Hyperactivity Disorder. Journal of Clinical Pharmacology, 18, 125. doi/10.3149/jms.2003.179

Karakis, E. N., \& Levant, R. F. (2012). Is Normative Male Alexithymia Associ Ated with Relationship Satisfaction, Fear of Intimacy and Communication Quality Among Men in Relationships? The Journal of Men's Studies, 20(3), 179-186. https://doi.org/10.3149/jms.2003.179

Koçak, R. (2003). The Effect of Emotional Expession of Educational Program Upon Alexithymia and Loneliness Level of Universty Students (phD Thesis). Ankara University: 1-30.

Koçak, R., (2002). Alekitimi: Theoretical Framework Treatment Approaches and Related Research., Ankara University. Journal of Faculty of Educational Sciences, 35(1-2), 9-212. https://doi.org/10.5455/cap.20130515054141 
Krystal, J. H., Güler, E. L., \& Cichetti, D. V. (1986). Assessment of Alexithymia in Posttraumatic Stress Disorder and Somatic Illness-Introduction of A Reliable Measure. Psychosom. Med, 48, 84-94. https://doi.org/10.1097/00006842-198601000-00007

Krystal, H. J. (1979). Alexihymia and Psychotherapy. American Journal of Psycotherapy, 31(1), 17-31.

Krystal, H. J. (1982). Alexithymia and Effectiveness of Psychoanalytic Treatment. International Journal of Psychonalytic Psychotherapy, 353.

Lakey, C. E., Rose, P., Campbell, W. K., \& Goodie, A. S. (2008). Probing the Linkbetween Narcissism and Gambling: The Mediating Role of Judgment and Decision-Making Biases. Journal ff Behavioral Decision Making, 21, 113-137. https://doi.org/10.1002/bdm.582

Lesser, I. M. (1981). A Review of the Alexithymia Concept. Psychosomatic Medicine, 43(6), 690-692. https://doi.org/10.1097/00006842-198112000-00009

Levant, R. F., Halter, M. J., Hayden, E. W., \& Williams, C. M. (2009). The Eficicacy of Alexithymia Reduction Treatment: A Pilot Study. Thee Journal of Men's Studies, 17(1), 75-84. https://doi.org/10.3149/jms.1701.75

Levant, R. F., Good, G. E., Cook, S. W., O’Neri, J. M., Smalley, K. B., \& Owen, K. (2006). The Normative Male Alexithymia Scale: Measurement of A Gender- Linked Syndrome. Psychology of Men and Masculinity, 7(4), 212-224. https://doi.org/10.1037/1524-9220.7.4.212

Llewellyn, D. J., \& Sanchez, X. (2008). Individual Differences and Risk-Taking in Rock Climbing. Psychology of Sport and Exercise, 9, 413-426. https://doi.org/10.1016/j.psychsport.2007.07.003

Llewellyn, D. J., Sanchez, X., Asghar, A., \& Jones, G. (2008). Self-Efficacy, Risk-Taking and Performance in Rock Climbing. Personality and Individual Differences, 45(1), 75-81. https://doi.org/10.1016/j.paid.2008.03.001

Luzumlu, U. (2013). Research Which Analyzes Different University Students' Styles of Coping with Stress According to Their Levels of Alexithymia. Master Thesis, Mersin Üniversity, Mersin.

Mattila, A. K., Kronholm, E., Jula, A., Salminen, J. K., Koivisto, A. M., Mielonen, R. L., \& Joukamaa, M. (2008). Alexithymia and Somatization in General Population. Psychosomatic Medicine, 70, 716-722. https://doi.org/10.1097/PSY.0b013e31816ffc39

Mattila, A. K., Salminen, J. K., Nummi, T., \& Joukamaa, M. (2006). Age Is Strongly Associated with Alexithymia in The General Population. Journal of Psychosomatic Research, 61, 629-635. https://doi.org/10.1016/j.jpsychores.2006.04.013

McLean, P. D. (1949). Pschosomatic Disease and The Visceral Brain. Psychosomic Medicine, 348-353.

Mishra, S., \& Lalumière, M. L. (2011). Individual Differences in Risk-Propensity: Associations Between Personality and Behavioral Measures of Risk. Personality and Individual Differences, 50(6), 869-873. https://doi.org/10.1016/j.paid.2010.11.037

Mishra, S., \& Lalumiére, M. L. (2010). You Can't Always Get What You Want: The Motivationel Effect Ofneed On Risk-Sensitive-Decission-Making. Journal of Experiment Al Social Psychology, 46, 605-611. https://doi.org/10.1016/j.jesp.2009.12.009

Mishra, S., \& Martin, L. L. (2010). You Can't Always Get What You Want: The Motivational Effect of Need on Risk-Sensitive Decision Making. Department of Psychology. Universty of Lethbridge. Journal of Expermental Social Psychology, 46, 605-611. https://doi.org/10.1016/j.jesp.2009.12.009

Monasterio, E. (2007). The Risk of Adventure Sports. Alpinst Newswire RSS, 1-2.

Muszkieta, R., \& Gembiak, M. (2004). Uwarunkowania I Motywy Uprawiania Sportów Ekstremalnych. In Z. Dziubiński (Ed.), Edukacja Poprzez Sport. Salezjańska Organizacji Sportowa RP (p. 478). Warszawa

Olds, J., \& Milner, P. (1954). Positive Reinforcement Produced by Electrical Stimulation of Septal Area and Other Regions of Rat Brain. J Comp Physiol Psychol, 47, 419-427. https://doi.org/10.1037/h0058775

Özeren, A. (2002). Afaziyoloji. Adana: Çukurova Üniversitesi Basımevi.

Öztan, P. (2006). The Relationship Between Learning Styles of Left and Right Brain Dominated Learners and Their Success in Foreign Language Teaching. Master Thesis, Ankara University, Ankara. 
Paetsch, J. J., \& Bertrand, L. D. (1997). The Relationship Between Peer, Social, And School Factors, And Delinquency Among Youth. Journal of School Health, 67(1), 27-32. https://doi.org/10.1111/j.1746-1561.1997.tb06291.x

Parker, J. D. A., Taylor, G. J., \& Bagby, R. M. (1998). Alexithymia: Relationship with Ego Defense and Coping Styles. Comprehensive Psychiatry, 39(2), 91. https://doi.org/10.1016/S0010-440X(98)90084-0

Parsons, J. J., Siegel, A. W., \& Cousins, J. H. (1997). Late Adolescent Risk-Taking: Effects of Perceived Benefits and Perceived Risk on Behavioral Intentions and Behavioral Change. J. of Adolescence, 20, 381392. https://doi.org/10.1006/jado.1997.0094

Pedersen, M. D. (1997). Perceptions of High-Risk Sport. Perceptual and Motor Skills, 85, 756-758. https://doi.org/10.2466/PMS.85.6.756-758

Pençe, S. (2000). Selebral Laterizasyon. Van Medical Journal, 7(3), 120-122.

Pizam, A., Jeong, G., Reichel, A., Boemmel, H. W., Lusson, J. M., \& Montmany, N. (2004). The Relation Between Risk-Taking Sensation Seeking and The Tourist Behavior of Young Adults: A Cross Cultural Study. Journal of Travel Research, 42, 251-260. https://doi.org/10.1177/0047287503258837

Rajola, E., \& O'Keefe, M. (1999). Philosophy in Practice: A History of Adventure Programming. In J. C. Miles \& S. Priest (Eds.), Adventure Programming State College (pp. 45-53). PA: Venture.

Ruesch, J. (1948). The Infantile Personality: The Core Problem of Psychosomatic Medicine. Psychosomatic Medicine, 134-144. https://doi.org/10.1097/00006842-194805000-00002

Ruigrok, A. N. V., Salimi-Khorshidi, G., Lai, M. C., Baron-Cohen, S., Lombardo, M. V., Tait, R. J., \&Suckling, J. (2014). A Meta-Analysis of Sex Differences in Human Brain Structure. Neuroscience \& Biobehavioral Reviews, 39, 34-50. https://doi.org/10.1016/j.neubiorev.2013.12.004

Selçuk, Z. (1989). University Students Self Disclosure. PhD thesis, Hacettepe University, Ankara.

Sifneos, P. E. (1972). Short-Term Psychotherapy and Emotional Crisis (pp. 133-136). Cambridge: Harvard University Press.

Sifneos, P. E. (1988). Alexithymia and Its Relationship to Hemispheric Specialization Affect and Creativity. Psychiatric Clinics of North America, 11(3), 287-293. https://doi.org/10.1016/S0193-953X(18)30480-5

Slanger, E., \& Rudestam, K. E. (1997). Motivation and Disinhibition in High Risk Sports: Sensation Seeking and Self-Efficacy. Journal of Research in Personality, 31(3), 355-374. https://doi.org/10.1006/jrpe.1997.2193

Stevens, J., \& Goldbers, D. (2001). For the Leaners's Sake: Brain Based Intruction for the 21st Century (p. 20). ABD: Zephyi Yay.

Şahin, R. A. (1991). Peptic Ulcer and Alexithymia. Turkish Journal of Psychiatry, 2(3), 25-30.

Taylor, G. J., Bagby, R. M., \& Parker, J. D. (1991). Alexithymia Construct, A Potantial Paradigm for Psycosomatic Medicine. The Academy of Pschosomatic Medicine, 32. https://doi.org/10.1016/S0033-3182(91)72086-0

Taylor, G. J. (1984). Alexithymia, Concept Measurement and Implications for Treatment. American Journal of Psychiatry, 141. https://doi.org/10.1176/ajp.141.6.725

TenHoughten, W. D., Hoppe, K. D., Bogen, J. E., \& Walter, D. O. (1986). Alexithymia an Experimental Study of Cerebral Commissurotomy Patients and Normal Control Subjects. American Journal of Psychiatry, 312316. https://doi.org/10.1176/ajp.143.3.312

TenHoughten, W. D., Walter, D. O., Hoppe, K. D., \& Bogen, J. E. (1987). Alexithymia and The Split Brain V. EEG. Alphaband İnterhemispheric Coherence Analysis. Psychotherapy and Psychosematics, 1-10.

TenHoughten, W. D., Hoppe, K. D., Bogen, J. E., \& Walter, D. O. (1985). Alexithymia and The Split Brain I. Lexical-Level Conent Analysis. Psychotherapy and Psychosomatic, 202-208. https://doi.org/10.1159/000287898

Uzbay, I. T. (2015). It Possible to Understand the Brain by Only Neuroscience? New Expansions and Approaches from Neurological Sciences to Social Sciences in The Brain Century. Usküdar University. Journal of Social Sciences, 1(1), 129.

Üngören, E. (2015). Beynin Nöroanatomik ve Nörokimyasal Yapısının Kişilik ve Davranış Üzerindeki Etkisi. Uluslararası Alanya İşetme Fakültesi Dergisi, 7(1). 
Wagenen, V. W., \& Herren, R. (1940). Surgical Division of Commissural Pathways in The Corpus Callosum. Arch Neurol Psychiatry, 44, 740-759.

Way, I., Yelsma, P., Van Meter, A. M., \& Block-Pond, C. (2007). Understanding Alexithymia and Language Skills I Children: Implicaions For Asseement and Intervention. Language. Speech and Hearing Services in Schools, 38(2), 132.

Weber, E. U. (2001). Outdoor Adventure Tourism a Review of Research Approaches. Annals of Tourism Research, 28(2), 360-377. https://doi.org/10.1016/S0160-7383(00)00051-7

Weber, E. U., Blais, A. R., \& Betz, N. (2002). A Domain-Specific Risk-Attitude Scale: Measuring Risk Perceptions and Risk Behaviors. Journal of Behavioral Decision Making, 15, 263-290. https://doi.org/10.1002/bdm.414

Wolfe, P. (2001). Brain Matters: Translating Research into Classroom Practice. Alexandra Virginia. Association for Supervision and Curriculum Development, 27. ISBN-978-1-4166-1067-0

Vazire, S., \& Funder, D. C. (2006). Impulsivity and The Self-Defeating Behavior of Narcissists. Personality and Social Psychology Review, 10(2), 154-165. https://doi.org/10.1207/s15327957pspr1002_4

Y1lmaz, T. (2000). Investigation of RiskTaking Behavior in Adolescence. Master Thsesis, Ege University, İzmir.

Yavaş Tez, Ö., \& Dinç, S., C. (2017). The Adaptation Study into Turkish of Domain Specific Risk Assessment Scale-Short Form (DOSPERT). World Congress of Sport Sciences Researches Abstract Book, 23-26 November 2017, Manisa/Turkey.

Zuckerman, M. (2007). The Sensation Seeking Scale V (SSS-V): Still Reliable and Valid. Personality and Individual Differences, 43, 1303-1305. https://doi.org/10.1016/j.paid.2007.03.021

\section{Copyrights}

Copyright for this article is retained by the author, with first publication rights granted to the journal.

This is an open-access article distributed under the terms and conditions of the Creative Commons Attribution license (http://creativecommons.org/licenses/by/4.0/). 